\title{
Anne Pemberton
}

\section{From friending to research Using Facebook as a teaching tool}

I have been a librarian for more than ten years, and, as Matthew McConaughey's character in "Dazed and Confused" says, "I get older and they [our students] stay the same age." The further away from our students' age I get, the less I feel like I am able to connect to them and connect information literacy concepts to them in the ways I could when I was first teaching.

I first noticed this when my comparison of subject headings to phone book headings brought glazed looks to the eyes of every student in the classroom. It dawned on me that many of them have never seen or used a phone book.

When Facebook launched in 2004, I, like many librarians, thought it would revolutionize the way I communicated with and related to students. I saw possibilities for promotion and outreach and quickly created a Facebook profile in hopes that students would be drawn to my smiling profile picture and would respond in droves to my offers of research help in my "information" section.

As I used Facebook more I began to realize that it would most likely not connect me to students in the ways I had hoped. A few years went by and while I, like our students, use Facebook almost addictively to share photos and eagerly await new status updates from friends, I have occasionally felt like Facebook was "the enemy" and went so far as to block it from the computers in my library instruction room so that students would pay attention to me instead of logging on to Facebook.

But it turns out that Facebook might just be a revolutionary tool for librarians after all. As I was tagging a Facebook photo of a friend of mine, it occurred to me that Facebook might just be one of the best teaching tools we have in our toolbox. "Tagging," I thought, "is very similar to controlled vocabulary!" I began to realize that I could teach students about information literacy concepts in a way that they would understand using Facebook.

I began experimenting with this in a threecredit hour course our library offers called, "LIB 103: Introduction to Library Research and Technology." Once I found some concepts that seemed to work, I was able to use them in "one shot" instruction sessions. These are a few of the concepts that I have found are fairly easy for students to understand because of their familiarity with Facebook. Some suggestions for introducing these concepts are also provided.

- You know what a database is because you use Facebook. I find that students rarely understand what the word database means. So trying to explain a library's online catalog or a subscription database can be difficult. But relating the catalog or a database to Facebook can help. You can start by asking students to raise their hand if they "are on Facebook." Nearly everyone will raise their hands.

You can then explain to them that they might think of themselves as a record in Facebook, just like each article is a record in a subscription database and each book is a record in the library catalog. You might ask for a volunteer to come up and log into their Facebook account. You can point out that each piece of information they provided (e.g., name, school, birth date) is a field in the record in the same way that the title, call

Anne Pemberton is instructional services coordinator at the University of North Carolina-Wilmington, e-mail: pembertona@uncw.edu

○ 2011 Anne Pemberton 
number, and author are fields in a catalog record.

You could also ask how many students have a MySpace account. Most likely only a few will raise their hands. You can explain that there is some overlap between the people, or records, that are in Facebook and MySpace in the same way that there may be overlap in subscription databases and discuss why you might need to search multiple databases to find what you are looking for.

- You know why there is a need for advanced searching because you use the feature in Facebook. Once students seem to have a better understanding of what a database actually is, you can relate the creation of a search strategy, advanced searching, and the concept of a subscription to searching Facebook.

You might explain that while you can go to Google and search for a person's name and see if they have a Facebook profile, you can't actually see information about that person without logging in. Subscription databases are the same way (but for different reasons, which you can explain). "Friending" in some ways is like "subscribing" to journals. Libraries have subscriptions to different journals in the same way that one student might have "access" to one set of Facebook friends and another student may have "access" to a different set of Facebook friends. There may be some overlap, however (insert humor about libraries paying for journal subscriptions and students not paying for friends on Facebook).

Once you log into Facebook you have the basic search box to go to where you might type someone's name. But what happens when 3,000 "Joe Smith" profiles appear? You must go to a more advanced search. So instead of reviewing all 3,000 profiles to find the one you are looking for, you can go to "Find Friends," run your search, and then "Filter" by location, school, or workplace. These are fields in Facebook. The same concept applies to searching the catalog or a subscription database. You can filter your results or limit them by searching for articles with certain words in the title or by specific author, or by date. You might even suggest that maybe someday Facebook could (or should) have as powerful a search interface as library databases by showing them ALL the ways you can limit and narrow a search. Prepare for the "ohs and ahs."

- Facebook tagging is similar to controlled vocabulary. I rarely use the phrase "subject headings" or "controlled vocabulary" anymore when I teach. With undergraduate students, I nearly always refer to this concept as "tagging."

To explain this concept you may have a student explain how and why they tag photos in Facebook. You might say, "Let's say you each had a picture of me and you tagged them with my name? What would happen?" They will likely explain that now, when anyone clicks on my name when looking at a tagged photo or when clicking on "View Photos of Me," that all the photos where I am tagged are all together in one place regardless of where each photo came from. You can then explain that library subject headings and database descriptors work in a similar way.

You might perform a keyword search in the library catalog and click on a title that's relevant to your search. Explain that if the student clicks on the subject heading for that book that this operates in the same way that a Facebook "tag" operates: all the books on this same topic will "come together." Of course you can use other analogies to reinforce the concept. You might compare this tagging in Flickr, for example, and discuss how libraries use a standard set of "tags," while Flickr uses user-generated "tags."

- Some Facebook users are concerned about privacy and libraries are, too. Privacy may not be an issue that comes up in a one-shot instruction session, but if privacy is something you want to address, you might use Facebook to help explain the concept. Students typically do not want their parents or professors to be their "friends" on Facebook and seem to understand that some of their information should not be public.

You might ask students why they don't want the "whole world" to view their pictures 
or their profile. Students might say, "I don't want my parents to know what I'm up to" or "I don't want someone to judge me for what I say or what pictures I have." You might infer that some students value their privacy and explain that libraries value all patrons' privacy and discuss the reasons why. It's a great way to start the conversation and allow students to participate in discussion on this issue.

- Library interfaces change just like the Facebook interface changes. Students often complain about how "complicated" library catalogs and library databases are, and how frustrated they get when an interface changes. If this comes up in a session you might talk about the fact that the Facebook interface also changes frequently, and while each student contributes content to the Facebook "database," the student themselves does not have control over the Facebook interface. This is the same as most library catalogs and library databases. It is usually the vendor that is responsible for the changes, and it is usually based on feedback from users.

Letting them know we realize that it is frustrating goes a long way and helps students understand that the library itself is not necessarily responsible for changes in subscription-based products.

- As a Facebook user, you are constantly evaluating information. You might ask students what they do when they encounter a friend's status update that relates to an item in the news. "When you see a friend's status update about a newsworthy event, what do you do?" Students will usually say that they click on a link if it's provided or they Google the headline. You might ask them why they don't just take their friend's word that the story is true. Having a discussion about why they feel the need to get more information and how that relates to their own research can be helpful in reinforcing the idea of information evaluation. A discussion about obtaining multiple sources of information and evaluating authority and currency should ensue.

Using Facebook as a starting point in library instruction has had a tremendous impact on my teaching. There are other concepts that I've related to Facebook, as well: "browsing versus searching," "information overload," "the complexity of information," "information growth," and others. I find students are interested in the session and they seem to grasp the concepts I'm discussing more firmly. It makes library instruction relevant and fun, and it has transformed my teaching style. I have moved from lecturing to a discussion-based approach, and I find that this has improved the outcome of my instruction sessions. These same concepts are just as applicable when answering questions at the reference desk. While we may not completely relate to students, we can at least try to help them relate to the concepts that they will need to understand to be information literate, and perhaps Facebook just might be one way to do that. $\boldsymbol{n}$

("Open access..." continued from page 19)

work of collaborating and cooperating with other libraries in Florida continues, as does the similarly long-term migration from print to digital resources. We also continue in our political work in our efforts to persuade Congress that passing the Federal Research Public Access Act (FRPAA, H.R. 5037) is good public policy that will improve access to federally funded research for researchers, consumers, and the students and faculty of liberal arts colleges. At least now Rollins can say we are putting our money where our mouth is.

\section{Note}

1. The College's OA Policy and institutional repository would not have come to fruition without the sustained effort of many people, including Thomas Moore, Archibald Granville Bush professor of science and professor of physics; Claire Strom, RapettiTrunzo chair of history; Bill Svitavsky, head of digital services and systems; David Noe, digital services librarian; Peter Suber, senior researcher at SPARC; and Jonathan Cadle, Berkeley Electronic Press. n 